\title{
KUALITAS MADU \\ (KEASAMAN, KADAR AIR, DAN KADAR GULA PEREDUKSI) BERDASARKAN PERBEDAAN SUHU PENYIMPANAN
}

\author{
Devyana Dyah Wulandari* \\ Prodi D-IV Analis Kesehatan, Fakultas Kesehatan \\ Universitas Nahdlatul Ulama Surabaya \\ *email : devyanadyah@unusa.ac.id
}

Received 22 Pebuari 2017

Accepted 9 April 2017

\begin{abstract}
Abstrak
Penyimpanan madu akan dapat mempengaruhi mutu. Suhu penyimpanan untuk madu yang terbaik adalah $36-38{ }^{\circ} \mathrm{C}$ dengan kelembaban $75-78$ persen. Dengan cara ini madu dapat tahan 2- 4 minggu lamanya tanpa banyak mengalami penurunan mutu. Oleh karena itu, peneliti ingin mengetahui pengaruh suhu penyimpanan terhadap kualitas madu nektar karet berdasarkan keasaman, kadar air, dan kadar gula pereduksi. Keasaman diukur menggunakan metode titrasi asam basa, kadar air diukur secara gravimetri, dan kadar gula pereduksi diukur dengan metode Luff Schrool. Madu suhu ruang $\left( \pm 25^{\circ} \mathrm{C}\right)$ memiliki kadar keasaman rata-rata $45 \mathrm{ml} \mathrm{NaOH} 0,1 \mathrm{~N} / \mathrm{kg}$ dan madu suhu dingin $\left( \pm 5^{\circ} \mathrm{C}\right)$ kadar keasaman rata-rata 32 $\mathrm{ml} \mathrm{NaOH} \mathrm{0,1N/kg.} \mathrm{Kadar} \mathrm{air} \mathrm{madu} \mathrm{suhu} \mathrm{ruang} \mathrm{rata-rata} \mathrm{28,595 \%} \mathrm{dan} \mathrm{kadar} \mathrm{air} \mathrm{madu} \mathrm{suhu}$ dingin rata-rata $27,112 \%$. kadar gula pereduksi, madu suhu ruang memiliki kadar gula pereduksi sebesar $51,625 \%$, sedangkan pada madu suhu dingin memiliki kadar gula pereduksi sebesar $62,5 \%$.
\end{abstract}

Kata kunci: Madu, keasaman, kadar gula pereduksi

\begin{abstract}
Storage condition could affect honey quality. $36-38^{\circ} \mathrm{C}$ is the suitable temperature for honey storage with humidity 75-78 percent. Honey can be lasting 2-4 weeks without severely degraded. Therefore, researchers wanted to determine the effect of storage temperature on the quality of honey from rubber trees nectar based acidity, the water content, and the levels of reducing sugars. Acidity is measured using acid-base titration method, water content is measured with gravimetry, and reducing sugar levels measured with Luff schrool method. In room temperature, honey has an average acidity of $45 \mathrm{ml} / \mathrm{kg} \mathrm{NaOH} 0,1 \mathrm{~N}$ and cold temperature average acidity of $32 \mathrm{ml} / \mathrm{kg} \mathrm{NaOH} 0,1 \mathrm{~N}$. The average water content of honey, in room temperature is $2,595 \%$ and $27,112 \%$ in cold temperature. For reducing sugar, under room temperature the content is about $51,625 \%$, while under cold temperature, the level reach $62,5 \%$.
\end{abstract}

Keywords: Honey, acidity, reducing sugars level

\section{Pendahuluan}

Madu adalah cairan alami yang umumnya mempunyai rasa manis yang dihasilkan oleh lebah madu dari sari bunga tanaman (floral nektar) atau bagian lain dari tanaman (ekstra floral nektar) atau 
ekskresi serangga (Gebremariam, 2014). Madu mengandung sejumlah senyawa dan sifat antioksidan yang telah banyak diketahui. Sifat antioksidan dari madu yang berasal dari zat-zat enzimatik (misalnya, katalase, glukosa oksidase dan peroksidase) dan zat-zat nonenzimatik (misalnya, asam askorbat, $\alpha$-tokoferol, karotenoid, asam amino, protein, produk reaksi Maillard, flavonoid dan asam fenolat). Jumlah dan jenis antioksidan ini sangat tergantung pada sumber bunga atau varietas madu, dan telah banyak banyak penelitian yang menunjukkan bahwa adanya hubungan antara aktivitas antioksidan dengan kandungan total fenol (Khalil, 2012). Masyarakat Indonesia menggunakan madu sebagai campuran pada jamu tradisional untuk meningkatkan khasiat penyembuhan penyakit seperti infeksi pada saluran cerna dan pernafasan, serta meningkatkan kebugaran tubuh. Madu juga memiliki kemampuan untuk meningkatkan kecepatan pertumbuhan jaringan baru (Wineri, 2014).

Madu mengandung banyak mineral seperti natrium, kalsium, magnesium, alumunium, besi, fosfor, dan kalium. Vitamin-vitamin yang terdapat dalam madu adalah thiamin (B1), riboflavin (B2), asam askorbat $(\mathrm{C})$, piridoksin (B6), niasin, asam pantotenat, biotin, asam folat, dan vitamin K. Sedangkan enzim yang penting dalam madu adalah enzim diastase, invertase, glukosa oksidase, peroksidase, dan lipase. Selain itu unsur kandungan lain madu adalah memiliki zat antibiotik atau antibakteri (Adji, S, 2004). Berikut ini komposisi kimia madu per 100 gram.

Di Indonesia, untuk kualitas madu sudah ditentukan berdasarkan Standar Nasional Indonesia (SNI) Nomor 01-35451994 seperti yang tercantum pada Tabel 2 . Dimana standar tersebut merupakan kriteria dari mutu madu yang telah

\section{Metode Penelitian}

Alat dan Bahan

Alat yang dibutuhkan selama penelitian antara lain erlenmeyer, gelas ukur, pipet ditetapkan oleh Badan Standarisasi Nasional (BSN) dan merupakan hasil revisi dari SNI tentang syarat mutu madu tahun 1992.

Tabel 1. Komposisi Madu berdasarkan SNI, 2004

\begin{tabular}{ll}
\hline Komposisi & Jumlah \\
\hline Kalori & $328 \mathrm{kal}$ \\
Kadar Air & $17,2 \mathrm{~g}$ \\
Protein & $0,5 \mathrm{~g}$ \\
Karbohidrat & $82,4 \mathrm{~g}$ \\
Abu & $0,2 \mathrm{~g}$ \\
Tembaga & $4,4-9,2 \mathrm{mg}$ \\
Fosfor & $1,9-6,3 \mathrm{mg}$ \\
Besi & $0,06-1,5 \mathrm{mg}$ \\
Mangan & $0,02-0,4 \mathrm{mg}$ \\
Magnesium & $1,2-3,5 \mathrm{mg}$ \\
Thiamin & $0,1 \mathrm{mg}$ \\
Riboflavin & $0,02 \mathrm{mg}$ \\
Niasin & $0,2 \mathrm{~g}$ \\
Lemak & $0,1 \mathrm{~g}$ \\
Ph & 3,9 \\
Asam & $43,1 \mathrm{mg}$ \\
\hline
\end{tabular}

Tabel 2. Kriteria Mutu Madu berdasarkan SNI, 2004

\begin{tabular}{llll}
\hline No. & Jenis Uji & Satuan & Persyaratan \\
\hline 1. & $\begin{array}{l}\text { Aktivitas enzim } \\
\text { diastase }\end{array}$ & $\mathrm{DN}$ & Min. 3 \\
2. & $\begin{array}{l}\text { Hidroksimetil- } \\
\text { furfural }\end{array}$ & $\mathrm{mg} / \mathrm{kg}$ & Maks. 40 \\
3. & Air & $\%$ & Maks. 22 \\
4. & Gula reduksi & $\% \mathrm{~b} / \mathrm{b}$ & Min. 60 \\
5. & Sukrosa & $\% \mathrm{~b} / \mathrm{b}$ & Maks. 10 \\
6. & Keasaman & $\mathrm{ml}$ & Maks. 40 \\
& & $\mathrm{NaOH}$ & \\
& & $1 \mathrm{~N} / \mathrm{kg}$ & \\
7. & $\begin{array}{l}\text { Padatan yang } \\
\text { tak larut dalam }\end{array}$ & & Maks. 0,5 \\
& $\begin{array}{l}\text { air } \\
\text { Abu }\end{array}$ & $\% \mathrm{~b} / \mathrm{b}$ & Maks. 0,5 \\
9. & $\begin{array}{l}\text { Cemaran logam } \\
\text { Timbal }(\mathrm{Pb})\end{array}$ & $\mathrm{mg} / \mathrm{kg}$ & Maks. 1,0 \\
& Tembaga $(\mathrm{Cu})$ & $\mathrm{mg} / \mathrm{kg}$ & Maks. 5,0 \\
10. & Cemaran arsen & $\mathrm{mg} / \mathrm{kg}$ & Maks. 5,0 \\
\hline
\end{tabular}

volume, buret, labu ukur, kaca arloji, pipet tetes. Bahan yang dibutuhkan selama penelitian antara lain larutan Luff Schoorl (Cara membuat: Larutkan 143,8 g Na $\mathrm{CO}_{3}$ 
anhidrat dalam akuades $\pm 300 \mathrm{ml}$. Sambil diaduk, tambahkan $50 \mathrm{~g}$ asam sitrat yang telah dilarutkan dengan $50 \mathrm{ml}$ akuades. Tambahkan $25 \mathrm{~g} \mathrm{CuSO}_{4} .5 \mathrm{H}_{2} \mathrm{O}$ yang telah dilarutkan dengan $100 \mathrm{ml}$ akuades. Pindahkan larutan tersebut kedalam labu ukur 1 liter, tepatkan sampai tanda batas dengan akuades dan kocok. Biarkan semalam dan saring bila perlu. Larutan ini mempunyai kepekatan $\mathrm{Cu}^{2+} 0,2 \mathrm{~N}$ dan $\mathrm{Na}_{2} \mathrm{CO}_{3} 2 \mathrm{M}$ ), larutan $\mathrm{KI} 20 \%$, larutan $\mathrm{H}_{2} \mathrm{SO}_{4} 3 \mathrm{M}$ dan $25 \%$, larutan $\mathrm{Na}_{2} \mathrm{~S}_{2} \mathrm{O}_{3} 0,1$ $\mathrm{N}$, larutan $\mathrm{HCl} 25 \%$, larutan $\mathrm{NaOH} 30 \%$, indikator kanji 0,5\%, akuades.

\section{Prosedur Kerja}

\section{Keasaman}

Sampel madu ditimbang dengan teliti 10,0 g kemudian dimasukkan kedalam erlenmeyer $250 \mathrm{ml}$ dan dilarutkan dengan $75 \mathrm{ml}$ air suling dan tambahkan 4 - 5 tetes indikator PP. selanjutnya dititrasi dengan larutan $\mathrm{NaOH} 0,1 \mathrm{~N}$ sampai titik akhir yang tetap selama 10 detik. Dicatat volume $\mathrm{NaOH}$ 0,1 N yang diperlukan selama titrasi. Sebagai alternatif, dapat digunakan $\mathrm{pH}$ meter dan sampel dititrasi sampai $\mathrm{pH}$ 8,3. Dihitung keasaman dalam madu dengan perhitungan menggunakan persamaan 1, dengan $a$, volume $\mathrm{NaOH} 0,1$ $\mathrm{N}$ yang digunakan dalam titrasi, $\mathrm{mL}, b$ adalah normalitas $\mathrm{NaOH} 0,1 \mathrm{~N}$ dan $c$, adalah bobot contoh, gram.

$$
\text { Keasaman }(\mathrm{mL} \mathrm{N} \mathrm{NaOH} / \mathrm{kg})=\frac{a \times b}{c} \times 1000
$$

\section{Kadar air}

Sampel ditimbang sebanyak 1-2 gram dan dimasukkan ke dalam botol timbang yang sudah diketahui beratnya. Sampel dimasukkan kedalam oven pada suhu 105$110^{\circ} \mathrm{C}$ selama 2 jam. Setelah itu sampel didinginkan dalam eksikator selama 10 menit kemudian ditimbang dan dimasukkan kedalam oven kembali selama 1 jam. Sampel didinginkan dalam eksikator selama 10 menit kemudian ditimbang kembali. Diulangi pemanasan dalam oven dan penimbangan sampai berat konstan (selisih penimbangan berturut- turut $\leq 0,2 \mathrm{mg}$ ) kemudian dihitung kadar air sampel dengan persamaan 2 .

$$
\text { Kadar Air }=\frac{\text { berat bahan }(\text { awal }- \text { akhir })}{\text { berat bahan awal }} \times 100 \%
$$

\section{Kadar gula pereduksi}

Pengujian ketepatan larutan Luff Schoorl Larutan Luff Schoorl dipipet sebanyak $25 \mathrm{ml}$ tambahkan $3 \mathrm{~g} \mathrm{KI}$ dan $25 \mathrm{ml}$ larutan $\mathrm{H}_{2} \mathrm{SO}_{4} 3 \mathrm{M}$. Titrasi dengan larutan $\mathrm{Na}_{2} \mathrm{~S}_{2} \mathrm{O}_{3}$ $0,1 \mathrm{n}$ dengan indikator kanji $0,5 \%$. Larutan $\mathrm{Na}_{2} \mathrm{~S}_{2} \mathrm{O}_{3}$ yang dibutuhkan seharusnya 25 ml. Larutan Luff Schrool harus mempunyai $\mathrm{pH}$ 9,3 - 9,4

\section{Penentuan kadar gula pereduksi}

Sampel ditimbang $2 \mathrm{~g}$ dan dimasukkan dalam labu ukur $250 \mathrm{ml}$, dan ditambah akuades sampai tanda batas dan kocok. Larutan dipipet $10 \mathrm{ml}$ dan dimasukkan dalam erlenmeyer. Larutan sampel ditambahkan $15 \mathrm{ml}$ akuades dan $25 \mathrm{ml}$ larutan Luff Schoorl (dengan pipet volume), erlenmeyer di hubungkan dengan pendingin tegak, dipanaskan diatas pemanas listrik, dan diusahakan dalam waktu 3 menit sudah harus mulai mendidih. Larutan sampel dipanaskan terus menerus selama 10 menit (memakai stopwatch) kemudian diangkat dan dinginkan dalam bak berisi es (tidak boleh digoyang). Setelah dingin ditambahkan 10 ml larutan KI 20\% dan 25 ml larutan $\mathrm{H}_{2} \mathrm{SO}_{4} 25 \%$ (hati-hati terbentuk gas $\mathrm{CO}_{2}$ ). Larutan kemudian dititrasi dengan larutan natrium tiosulfat $0,1 \mathrm{~N}$ dengan indikator larutan kanji 0,5\% ( $\left.\mathrm{V}_{1}\right)$. Penetapan blanko dilakukan dengan sampel berisi $25 \mathrm{ml}$ air dan 25 ml larutan Luff Schoorl seperti diatas $\left(\mathrm{V}_{2}\right)$.

\section{Penentuan kadar sukrosa}

Sampel ditimbang $2 \mathrm{~g}$ dan dimasukkan dalam labu ukur $250 \mathrm{ml}$, kemudian ditambah akuades sampai tanda batas dan dikocok. Larutan dipipet $50 \mathrm{ml}$ masukkan dalam labu ukur $100 \mathrm{ml}$ dan ditambah 25

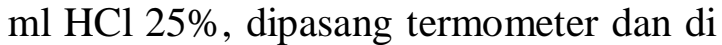
hidrolisis diatas penangas air. Apabila 
suhu mencapai $68^{\circ} \mathrm{C} \quad-70^{\circ} \mathrm{C}$ suhu dipertahankan selama tepat 10 menit. Termometer diangkat dan dibilas dengan air, dan didinginkan. Larutan $\mathrm{NaOH} 30 \%$ ditambahkan sampai netral (warna merah jambu) dengan indikator PP dan ditambahkan aquades sampai tanda batas kemudian dikocok. Larutan tersebut dipipet $10 \mathrm{ml}$ dan dimasukkan kedalam erlenmeyer. Akuades ditambahkan sebanyak $15 \mathrm{ml}$ dan $25 \mathrm{ml}$ larutan Luff Schoorl (dengan pipet volume). Erlenmeyer dihubungkan dengan pendingin tegak, dipanaskan diatas pemanas listrik, dan diusahakan dalam waktu 3 menit sudah harus mulai mendidih. Larutan terus dipanaskan selama 10 menit (memakai stopwatch) kemudian diangkat dan dinginkan dalam bak berisi es (tidak boleh digoyang).Setelah dingin ditambahkan 10 ml larutan KI $20 \%$ dan $25 \mathrm{ml}$ larutan $\mathrm{H}_{2} \mathrm{SO}_{4} 25 \%$ (hati-hati terbentuk gas $\mathrm{CO}_{2}$ ). Larutan dititrasi dengan larutan natrium tiosulfat $0,1 \mathrm{~N}$ dengan indikator larutan kanji 0,5\% (V1). Blanko dilakukan dengan sampel berisi $25 \mathrm{ml}$ air dan $25 \mathrm{ml}$ larutan Luff Schoorl seperti diatas (V2).

\section{Hasil dan Pembahasan}

\section{Keasaman Madu}

Keasaman madu merupakan salah satu parameter yang digunakan untuk menentukan kualitas madu. Kadar keasaman ini menunjukkan jumlah asam bebas per $\mathrm{kg}$ madu. Pada penelitian ini diperoleh data keasaman untuk sampel madu pada suhu dingin dan suhu ruang.

Pada madu suhu ruang memiliki kadar keasaman rata-rata $45 \mathrm{ml} \mathrm{NaOH} 0,1 \mathrm{~N} / \mathrm{kg}$ dan madu suhu dingin kadar keasaman rata-rata $32 \mathrm{ml} \mathrm{NaOH} 0,1 \mathrm{~N} / \mathrm{kg}$. Kedua sampel menunjukkan memenuhi persyaratan mutu madu yaitu maksimal 50 $\mathrm{ml} \quad \mathrm{NaOH} \quad 0,1 \mathrm{~N} / \mathrm{kg}$. Semakin meningkatnya kadar keasaman merupakan suatu indikator telah terjadinya proses fermentasi dan proses transformasi alkohol menjadi asam organik. Dari hasil penelitian kadar keasaman diperoleh kesimpulan bahwa penyimpanan madu pada suhu dingin lebih disarankan daripada suhu ruang, karena pada suhu ruang tingkat kelembaban lebih tinggi, sehingga madu lebih mudah menyerap air, dengan kadar air tinggi akan lebih mudah menyebabkan terjadinya fermentasi. Hal inilah yang menyebabkan kadar keasaman madu pada suhu ruang lebih tinggi daripada madu suhu dingin.

Tabel 3. Keasaman madu

\begin{tabular}{lcc}
\hline Kadar & \multicolumn{2}{c}{ Suhu Madu } \\
keasaman & Ruang & Dingin \\
\hline Pengukuran I & 44 & 31 \\
Pengukuran II & 46 & 33 \\
Rerata & $\mathbf{4 5}$ & $\mathbf{3 2}$ \\
\hline
\end{tabular}

\section{Kadar air}

Pada hasil penelitian diperoleh kadar air madu karet pada suhu ruang dan suhu dingin sebagai berikut. Dari hasil penelitian diperoleh bahwa kadar air pada madu nektar karet baik pada suhu ruang maupun suhu menunjukkan diatas kadar maksimal menurut SNI, 2004, yaitu sebesar 22\%. Hal ini bisa dipengaruhi oleh beberapa faktor. Kadar air madu dipengaruhi kelembaban lingkungan yang ada. Hal ini disebabkan karena madu mempunyai sifat higroskopis, yaitu mudah menyerap air. Semakin tinggi kelembaban lingkungan maka kadar air madu akan semakin tinggi pula. Jika kelembapan $51 \%$, kadar air madu $16,1 \%$. Jika kelembapan $81 \%$, kadar air madu 33,4\% (Sarwono, 2007). Kadar air madu di Indonesia tinggi disebabkan oleh kelembaban relatif ( $\mathrm{Rh}$ ) udara di Indonesia yang tinggi (Gojmerac, 1983). Kelembaban relatif (Rh) Indonesia berkisar $60 \%$ hingga 90\%, menghasilkan kadar air madu sekitar 18,3\% sampai 33,1\% (Sihombing, 2005).

Kadar air yang rendah akan menjaga madu dari kerusakan untuk jangka waktu yang relatif lama. Prasetya and Andi (2014) menjelaskan bahwa kandungan kadar air yang tinggi pada madu akan merangsang aktifitas khamir untuk tumbuh 
dan berkembang dalam madu. Umur panen juga mempengaruhi komposisi air pada madu. Madu yang dipanen pada umur tua mempunyai kadar air lebih sedikit daripada madu yang dipanen pada umur yang lebih muda. Semakin lama madu dalam sarang lebah maka penguapan kadar air pada madu akan semakin sempurna.

Tabel 4. Kadar air dalam madu

\begin{tabular}{lll}
\hline Kadar Air & \multicolumn{2}{c}{ Suhu Madu } \\
& Ruang & Dingin \\
\hline Pengukuran I & 28,590 & 27,124 \\
Pengukuran II & 28,599 & 27,100 \\
Rerata & $\mathbf{2 8 , 5 9 5}$ & $\mathbf{2 7 , 1 1 2}$ \\
\hline
\end{tabular}

\section{Kadar Gula Pereduksi}

Penentuan kadar gula pereduksi dilakukan dengan metode Luff Shcrool. Metode Luff Schoorl didasarkan pada proses reduksi $\mathrm{Cu}^{2+}$ menjadi $\mathrm{Cu}^{+}$oleh gula pada madu. Larutan Luff Schoorl mengandung ion $\mathrm{Cu}^{2+}$. Gula pereduksi seperti glukosa dan fruktosa akan mereduksi $\mathrm{CuO}$ menjadi $\mathrm{Cu}_{2} \mathrm{O}$ (SNI 2004). Menurut Harjadi (1992) tahapan reaksi yang terjadi pada penetapan kadar gula dengan metode Luff Schoorl adalah sebagai berikut:

$$
\begin{gathered}
\mathrm{R}-\mathrm{CHO}+2 \mathrm{CuO} \rightarrow \mathrm{Cu}_{2} \mathrm{O}+\mathrm{R}-\mathrm{COOH} \\
\mathrm{H}_{2} \mathrm{SO}_{4}+\mathrm{CuO} \rightarrow \mathrm{CuSO}_{4}+\mathrm{H}_{2} \mathrm{O} \\
\mathrm{CuSO}_{4}+2 \mathrm{KI} \rightarrow \mathrm{CuI}_{2}+\mathrm{K}_{2} \mathrm{SO}_{4} \\
2 \mathrm{CuI}_{2} \rightarrow \mathrm{Cu}_{2} \mathrm{I}_{2}+\mathrm{I}_{2} \\
\mathrm{I}_{2}+2 \mathrm{Na}_{2} \mathrm{~S}_{2} \mathrm{O}_{3} \rightarrow \mathrm{Na}_{2} \mathrm{~S}_{4} \mathrm{O}_{6}+2 \mathrm{NaI}
\end{gathered}
$$

Kadar gula pereduksi ditunjukkan oleh kadar gula sebelum inversi, sedangkan kadar sukrosa ditunjukkan oleh selisih kadar gula sebelum dan sesudah inversi. Reaksi inversi gula sebagai berikut:

Sukrosa $\stackrel{\text { Enzim Invertase }}{\longrightarrow}$ Glukosa + Fruktosa

Pada penelitian ini dilakukan pengukuran kadar gula pereduksi pada madu yang disimpan pada suhu ruang dan suhu dingin. Hasil penelitian menunjukkan bahwa pada madu suhu ruang memiliki kadar gula pereduksi sebesar 51,625\%, sedangkan pada madu suhu dingin memiliki kadar gula pereduksi sebesar 62,5\%. Berdasarkan data SNI,2004 kadar gula pereduksi madu minimal $65 \%$, maka dapat disimpulkan bahwa madu suhu dingin memiliki kadar gula pereduksi lebih baik daripada madu suhu ruang. Ada beberapa faktor yang mempengaruhi kadar gula pereduksi madu antara lain, kadar air, kelembapan, dan masa panen. Ada penelitian yang menunjukkan bahwa kandungan air yang tinggi pada madu dapat merangsang aktivitas khamir untuk tumbuh dan berkembang di dalam madu, sehingga menyebabkan proses fermentasi. Khamir penyebab fermentasi pada madu adalah yeast osmophilic dari genus Zygosaccharomyces, yang tahan terhadap konsentrasi gula tinggi, sehingga dapat hidup dan berkembang dalam madu. Khamir di dalam madu akan mendegradasi gula, khususnya dekstrosa dan levulosa menjadi alkohol dan $\mathrm{CO}_{2}$, sehingga berpengaruh terhadap kandungan dekstrosa (glukosa) dan levulosa (fruktosa) madu. Hal ini diduga menjadi penyebab kandungan glukosa pada madu suhu ruang lebih rendah daripada madu suhu dingin karena madu suhu ruang memiliki kadar air lebih tinggi daripada madu suhu dingin.

Berdasarkan data kadar keasaman, kadar air, dan kadar gula pereduksi dapat disimpulkan bahwa penyimpanan madu lebih baik dilakukan di suhu dingin. Berdasarkan data kadar gula sebelum dan sesudah inversi dapat dihitung persentase kadar sukrosa. Hasil penelitian menunjukkan bahwa pada madu suhu ruang memiliki kadar sukrosa sebesar $4,156 \%$ dan pada madu suhu dingin memiliki kadar sukrosa sebesar $6,175 \%$. Namun, berdasarkan data SNI 2004 kadar sukrosa maksimum sebesar 5\%. Hanya madu suhu ruang yang memiliki kadar sukrosa memenuhi standar. Kadar sukrosa pada madu dapat dipengaruhi oleh keberadaan enzim invertase, yaitu enzim yang mengubah sukrosa menjadi glukosa dan fruktosa. Suhu optimum enzim invertase berkisar antara $30^{\circ}-50^{\circ} \mathrm{C}$ (El 
sayed, 2015). Kadar sukrosa pada madu suhu ruang lebih rendah daripada madu suhu dingin karena enzim invertase lebih aktif pada suhu ruang daripada suhu dingin. Berdasarkan persamaan reaksi 1 , dapat disimpulkan bahwa pada madu yang disimpan pada suhu dingin, enzim

\section{Kesimpulan}

Berdasarkan hasil penelitian, dapat diambil beberapa kesimpulan berikut:

1. Berdasarkan data keasaman, diperoleh data bahwa madu suhu ruang memiliki kadar keasaman rata-rata $45 \mathrm{ml} \mathrm{NaOH}$ $0,1 \mathrm{~N} / \mathrm{kg}$ dan madu suhu dingin kadar keasaman rata-rata $32 \mathrm{ml} \mathrm{NaOH}$ $0,1 \mathrm{~N} / \mathrm{kg}$. Kedua sampel menunjukkan telah memenuhi persyaratan mutu madu yaitu maksimal $50 \mathrm{ml} \mathrm{NaOH}$ $0,1 \mathrm{~N} / \mathrm{kg}$.

2. Berdasarkan data kadar air, diperoleh data kadar air madu suhu ruang ratarata $28,595 \%$ dan kadar air madu suhu dingin rata-rata $27,112 \%$. Kedua sampel menunjukkan kadar air diatas batas maksimum SNI yaitu $22 \%$. Dapat disimpulkan penyimpanan madu pada suhu dingin lebih disarankan daripada suhu ruang, karena pada suhu ruang tingkat kelembaban lebih tinggi, sehingga madu lebih mudah menyerap air, dengan kadar air tinggi akan lebih mudah menyebabkan terjadinya fermentasi.

\section{Daftar Pustaka}

El Sayed, 2015. Antimicrobial Activities of Saudi Honey against Pseudomonas aeruginosa. Saudi Journal of Biological Sciences 20,

Gebremariam, T., Brhane, G. 2014, Determination Of Quality And Adulteration Effects Of Honey From Adigrat And Its Surrounding Areas. International Journal of Technology Enhancements And Emerging Engineering Research, 2, 2347-4289 invertase menjadi tidak aktif, mengakibatkan proses hidrolisis sukrosa menjadi glukosa dan fruktosa menjadi terhambat, akibatnya kadar gula pereduksi menjadi lebih rendah daripada standar SNI.

3. Berdasarkan data kadar gula pereduksi, madu suhu ruang memiliki kadar gula pereduksi sebesar 51,625\%, sedangkan pada madu suhu dingin memiliki kadar gula pereduksi sebesar $62,5 \%$. Berdasarkan data SNI,2004 kadar gula pereduksi madu minimal $65 \%$, maka dapat disimpulkan bahwa madu suhu dingin memiliki kadar gula pereduksi lebih baik daripada madu suhu ruang. Sedangkan untuk kadar sukrosa, madu suhu ruang memiliki kadar sukrosa sebesar $4,156 \%$ dan pada madu suhu dingin memiliki kadar sukrosa sebesar $6,175 \%$. Namun, berdasarkan data SNI 2004 kadar sukrosa maksimum sebesar 5\%. Dapat disimpulkan bahwa kadar sukrosa pada madu suhu ruang lebih rendah daripada madu suhu dingin karena enzim invertase lebih aktif pada suhu ruang daripada suhu dingin.

\section{Ucapan Terimakasih}

Peneliti mengucapkan terimakasih kepada Laboratorium Biokimia Universitas Nahdlatul Ulama Surabaya yang telah memberikan izin untuk melakukan penelitian.

Gojmerac, W. L., 1983. Bees, Beekeeping, Honey and Pollination. Saybrook Press. Westport USA.

Harjadi, 1992, Konsep Dasar Kimia Analitik. Jakarta (ID): UI Press.

Khalil, I. M., 2012, Physicochemical and Antioxidant Properties of Algerian Honey. Molecules, 17, 11199-11215

Nadhilla, N. F., 2014, The Activity Of Antibacterial Agent Of Honey Against Staphylococcus aureus. J. Majority, 3 
Prasetya and Andi., B, 2014). Standar Nasional Indonesia (SNI) nomor Perbandingan Mutu Madu Lebah Apis Mellifera Berdasarkan Kandungan Gula Pereduksi Dan Non Pereduksi Di Kawasan Karet (Hevea brasiliensis) Dan Rambutan (Nephelium Lappaceum). Universitas Brawijaya Sarwono, B., 2007, Lebah Madu. Jakarta Selatan: AgroMedia Pustaka.

Sihombing, D. T. H., 2005, Ilmu Ternak Lebah Madu. Yogyakarta: Gadjah Mada University Press. 01-3545-2004 tahun 2004 tentang Madu

Wineri, E., 2014, Perbandingan Daya Hambat Madu Alami dengan Madu Kemasan secara In Vitro terhadap Streptococcus beta hemoliticus Group A sebagai Penyebab Faringitis. Jurnal Kesehatan Andalas. 3 